\title{
The conservation status of slow lorises Nycticebus spp. in Singapore
}

\author{
S. D. Fam ${ }^{1,6,7, *}$, B. P. Y-H. Lee ${ }^{2,3}$, M. Shekelle ${ }^{1,4,5}$ \\ ${ }^{1}$ Department of Biological Sciences, National University of Singapore, Singapore 119077, Singapore \\ ${ }^{2}$ Durrell Institute of Conservation and Ecology, School of Anthropology and Conservation, University of Kent, \\ Canterbury CT2 7NR, UK \\ ${ }^{3}$ National Parks Board, 1 Cluny Road, Singapore 259569, Singapore \\ ${ }^{4}$ Department of Anthropology, Western Washington University, Bellingham, WA 98229-6045, USA \\ ${ }^{5}$ Primate Research Institute for Cognition and Ecology, Ewha Womans University, Seoul 120-750, Republic of Korea \\ ${ }^{6}$ Present address: School of Archaeology and Anthropology, The Australian National University, Canberra, ACT 0200, Australia \\ ${ }^{7}$ Present address: South-east Asian Biodiversity Society, 504 Choa Chu Kang Street 51, Singapore 680504, Singapore
}

\begin{abstract}
Historically, the greater slow loris Nycticebus coucang has proven to be an elusive animal in Singapore, evading even the prolific British colonial animal collectors. In recent decades, sightings of the slow loris have increased remarkably, and these have coincided with an increase in nocturnal surveys. Past trade-record discrepancies, as well as the sighting in the wild of a non-native slow loris species, point to the importance of Singapore for global slow loris conservation. The first ever ecological survey is documented in this paper, highlighting the difficulty of studying the slow loris in the wild, in habitats hemmed in by urban development, as well as the urgency of further work on Singapore's most poorly studied primate.
\end{abstract}

KEY WORDS: Nycticebus $\cdot$ Trade $\cdot$ Trafficking $\cdot$ Ecology $\cdot$ Singapore $\cdot$ Conservation

\section{INTRODUCTION}

The greater slow loris Nycticebus coucang is an elusive animal in Singapore. Curiously, although the colonial naturalists were prolific collectors of mammals, no specimen originating from the rainforests of Singapore Island has been collected. The distribution and presence of $N$. coucang in Singapore is unclear, due to scant sightings and the presence of exotic, released pets (Lim et al. 2008). These uncertainties were raised as early as the 1960s by Harrison (1966). Although there has been a recent increase in interest in nocturnal zoology, sightings of slow lorises have remained sporadic.

The Singapore Red Data Book (2008) classifies N. coucang as 'critically endangered' (Lim et al. 2008), and the genus is under CITES (Convention on Inter- national Trade in Endangered Species of Wild Fauna and Flora) Appendix I protection (Nekaris \& Jaffe 2007). In order to be listed as 'critically endangered' for the Singapore Red Data Book, a species must number 'fewer than 50 mature individuals, OR if more than 50 mature individuals but less than 250, show some evidence of decline or fragmentation' (Davison 2008). Substantial areas of contiguous forest are required to support healthy slow loris populations (Nekaris \& Bearder 2007). Home ranges average nearly 20 ha (Wiens \& Zitzmann 2003a,b), but Bukit Timah and the Central Catchment Nature Reserves total only about 3000 ha (National Parks Board 2007), of which about half are reservoirs and the remainder highly fragmented. Hence, populations of $N$. coucang in Singapore, if any exist, will be very small. Habitat loss (Barrett 1981) and the pet 
trade may aggravate the problem (Ratajszczak 1998, Malone et al. 2002, Shepherd et al. 2004, Nekaris \& Bearder 2007, Nekaris \& Jaffe 2007, Nekaris \& Nijman 2007).

We hypothesise that slow lorises exist in Singapore, but amongst a mixture of native (greater slow) and exotic slow lorises. We further hypothesise that anecdotal reports can be attributed to release of slow lorises by traders and/or owners. To test the hypotheses, the first ever ecological study of slow lorises in Singapore was conducted. We collated as many sightings that have been recorded in Singapore as possible. We also examined Singapore's trade records in the CITES trade database, collected confiscation records as far back as possible and assessed threats to native slow lorises.

\section{MATERIALS AND METHODS}

\section{Geography and climate of Singapore}

Singapore is a diamond-shaped island at the southernmost tip of the Malay Peninsula. Previously possessing up to $95 \%$ forest cover island-wide (Brook et al. 2003), the pressure of economic and infrastructural development has seen the forest cover decline towards the Central Catchment and the north-western side of the island. The forests of central Singapore consist of 2 main reserves: the Central Catchment Nature Reserve (CCNR) and the 164 ha Bukit Timah Nature Reserve (BTNR), which is the last of the dipterocarp primary forest that was once the main forest cover of Singapore. Singapore also has a number of nature parks, which are a mixture of park, scrubland and various stages of secondary forest growth. The parks and reserves are small and discontinuous, and local biologists often rue the construction of the Bukit Timah Expressway (BKE) that severed the natural connection between the BTNR and CCNR. In recent years, the government has begun the process of reconnecting these forested areas through the construction of the ecolink, a habitat corridor over the BKE, as well as a network for park connectors that link various disparate nature parks together.

\section{Night surveys}

We conducted night surveys with a Petzl Micro 3.0 V headlamp with a halogen bulb and red filter, a Mini-Maglite, a high-intensity $50 \mathrm{~W}$ portable lamp, a pair of binoculars, a video camera with tripod, and a GPS receiver. The following areas were the study sites (Fig. 1): BTNR and its periphery, Nee Soon Swamp Forest (NSSF) and Thomson Ridge of the CCNR, and other places for which slow loris sightings were reported to the researcher via an appeal on www.wildsingapore.per.sg. To reduce disturbance, we used existing trails as transects as far as possible, so that moving through thick vegetation was avoided (Duckworth 1998), and limited group size to a maximum of 3 people (Charles-Dominique \& Bearder 1979). The transects were all surveyed at least twice at speeds of less than $1 \mathrm{~km} \mathrm{~h}^{-1}$.

Upon every encounter, the following data were taken if possible: time of sighting and duration (if animal was followed), number of animals, substrate size, height of slow loris from the ground and tree height, diameter at breast height (DBH) of the tree, tree species, activity at first contact, reaction to contact and subsequent activity after contact, and GPS coordinates. Each sighting was accompanied by a photo-

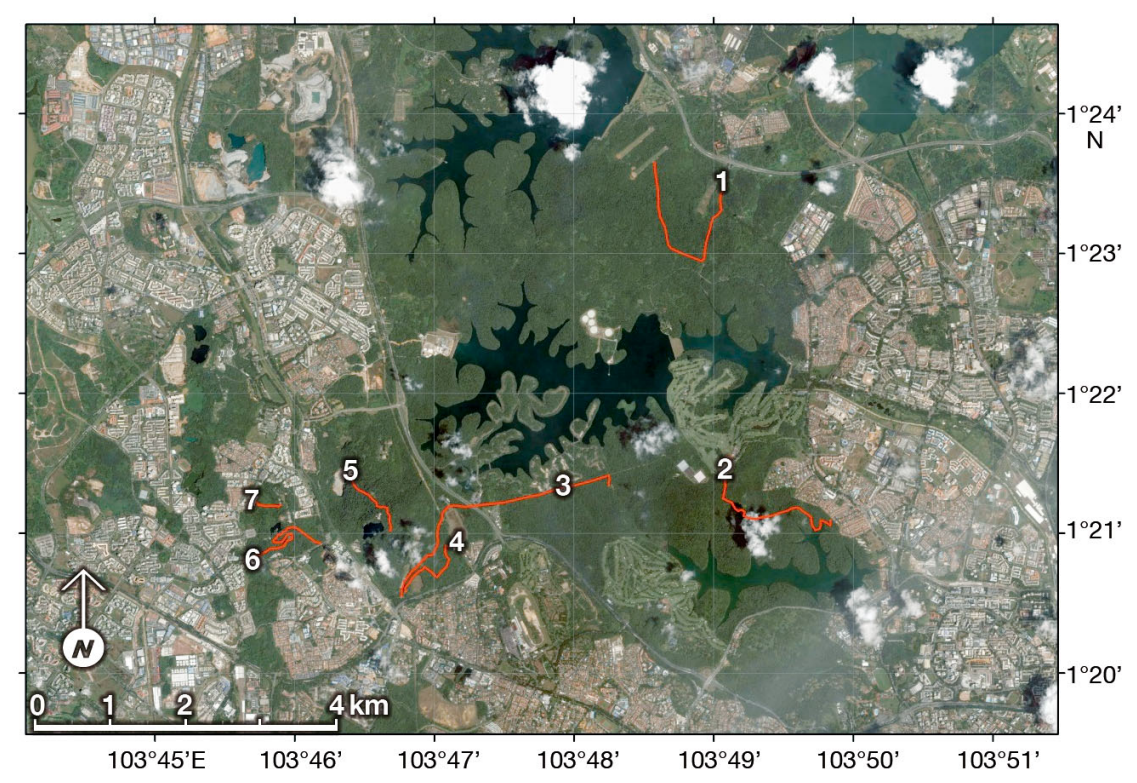

Fig. 1. Location of the 7 transects (red lines) used in surveys. 1: Nee Soon Swamp Forest; 2: Thomson Ridge; 3: Rifle Range area; 4: Kampong Trail; 5: Bukit Timah Nature Reserve; 6: Bukit Batok Nature Park; 7: forest near Meralodge Condominium. Map drawn with ArcGIS 9.0, with satellite photograph from Google Earth overlaid with GIS boundary map from National Parks Board database. Much of the forest area (with the exception of Nee Soon Swamp Forest; Transect 1) is bounded by heavy development and fragmented by roads, 
graph and/or video when possible. Numbers of individuals were counted for all vertebrate species observed at study sites (except for long-tailed macaques Macaca fascicularis, for which the number of troops was counted). These were contrasted with the rates of finding slow lorises, as an indication of their relative abundance.

\section{Trade and trafficking data and local reports}

Information on trafficked slow lorises was compiled based on the database kindly provided by Care for the Wild International up to 2008. This was compared to local slow loris sightings, including the records made by the Nature Society for the period of 1987 to 2008. Further trade information was obtained from the CITES trade database.

We also collated sightings of slow lorises in the wild from other sources, from 1965 to the present. Data were collected from a mixture of contributions from local zoologists, the Nature Society Singapore and personal data from the authors. We then mapped these sightings onto a map of Singapore.

Newspaper reports of the illegal trade and confiscation of slow lorises in Singapore were also searched by using a combination of Google and NewspaperSG, an online resource provided by the National Library Board containing current and historic Singapore newspapers published between 1831 and 2009. The search terms were 'slow loris' AND
'Singapore' AND 'trade' for Google and 'slow loris' for NewspaperSG.

\section{RESULTS}

\section{Night surveys}

We sighted slow lorises on 2 separate surveys at NSSF, a habitat characterised by freshwater swamp, fragmented by a wide concrete water pipeline. The first sighting was a Nycticebus pygmaeus, which represents an example of a smuggled pet (the only possible explanation as the species is not native to Singapore). The second sighting was N. coucang. Both sightings were made directly above the transect, where the canopies on both sides were bridged by over-reaching branches or rattan fronds. The slow lorises were observed crossing the transect using such areas of connectivity.

We spent a total of $108 \mathrm{~h}$ surveying 7 sites, and sighted slow lorises at a mean rate of $0.07 \mathrm{~h}^{-1}$ at NSSF (Fig. 2). The transect length at NSSF was $2.8 \mathrm{~km}$, and was surveyed 3 times for a total effort of $8.4 \mathrm{~km}$, yielding a mean encounter rate of $0.24 \mathrm{~km}^{-1}$. As only 1 of the 2 slow lorises observed is known to be $N$. coucang, the encounter rate for $N$. coucang was only $0.12 \mathrm{~km}^{-1}$. When all the sites are combined, $58.3 \mathrm{~km}$ were surveyed in total, with an $N$. coucang encounter rate of $0.017 \mathrm{~km}^{-1}$, much lower than that for other vertebrates during the same study.

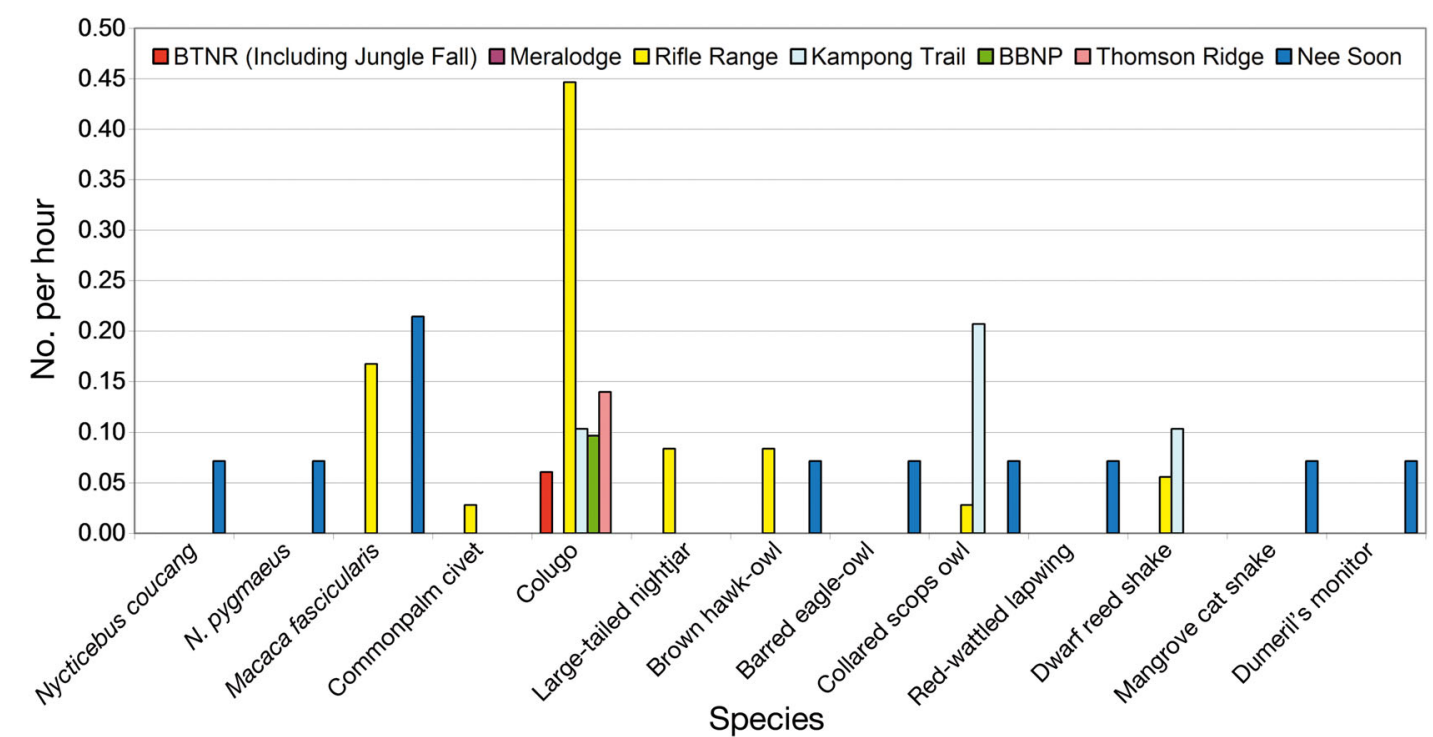

Fig. 2. The rate of sightings per hour of surveys for each site, calculated by dividing the number of sightings for each species at a particular site by the total number of hours spent there. BTNR: Bukit Timah Nature Reserve; BBNP: Bukit Batok Nature Park. Where we found colugos, no slow lorises Nycticebus spp. were encountered. Nee Soon Swamp Forest was also found to be harbouring rare species, such as the Dumeril's monitor and barred eagle owl. None of the species listed in this figure appeared at Meralodge 


\section{Trade and trafficking data and local reports}

In 1986, Singapore declared an export of 78 live slow lorises to Japan for trade purposes, but no mention was made of the sources of the exported slow lorises. In 1987, Singapore declared the import of 238 slow lorises from Laos, of which 218 were re-exported to Japan. However, the Japanese received a total of 228 slow lorises in the same shipment from Singapore, with no explanation from either party for the sudden appearance of 10 slow lorises. The same problems cropped up again in 1988, with Singapore importing and re-exporting 137 live slow lorises from Laos to Japan, and the Japanese receiving 269 slow lorises in this shipment, an unexplained excess of 162 slow lorises. Although the declarations were made for $N$. coucang, they were probably largely $N$. bengalensis, which is the native species in Laos most likely confused with $N$. coucang (the other being the easily identifiable N. pygmaeus). Declared trade in

Table 1. Chronological records of slow lorises Nycticebus spp. from Singapore. BTNR: Bukit Timah Nature Reserve; CCNR: Central Catchment Nature Reserve. Other than records 16 and 17, all refer to records of N. coucang. Most of the slow loris records come from seasoned naturalists so they are considered reliable. Efforts were made to clarify records from the public before publishing in 'The Pangolin', the newsletter edited and published by The Nature Society Singapore. Sightings from BTNR and CCNR were mainly made by experienced field workers or the relevant reserve staff. Records 17 and 18 originate from the field survey of this study. A specific date is shown for each sighting where possible. If it was not possible for the observers to recall the exact date, only the year of sighting is given

\begin{tabular}{|c|c|c|c|}
\hline No. & Date & Location & Notes \\
\hline 1 & 1965 & CCNR & $\begin{array}{l}\text { One seen by the observer. The observer also claimed that he heard this species 'call } \\
\text { regularly there between 1967-1969' (The Pangolin, Vol. 1(1), Apr 1988, p. 12). }\end{array}$ \\
\hline 2 & 25 Jan 1974 & $\begin{array}{l}\text { Geylang, } \\
\text { Southeast } \\
\text { Singapore }^{\mathrm{a}}\end{array}$ & $\begin{array}{l}\text { 'Tail-less creature' found sleeping in the backyard of observer's home. } \\
\text { Most probably an escapee (The Pangolin, Vol. 3(1-4), Mar-Dec 1990, p. 4). }\end{array}$ \\
\hline 3 & 1986 & $\begin{array}{l}\text { Jurong, West } \\
\text { Singapore }^{\mathrm{a}}\end{array}$ & $\begin{array}{l}\text { One seen and captured by army guard at 3rd Division, Jurong Camp, at Upper Jurong } \\
\text { Road. }\end{array}$ \\
\hline 4 & $1987-1988$ & Pulau Tekong & $\begin{array}{l}\text { One caught by villager between } 1987 \text { and } 1988 \text { (The Pangolin, Vol. 3(1-4), Mar-Dec } \\
\text { 1990, p. 4). }\end{array}$ \\
\hline 5 & Feb 1987 & CCNR & Caught by jogger and kept in canteen (The Pangolin, Vol. 2(3), Sep 1989, p. 36). \\
\hline 6 & 24 Aug 2002 & Beside CCNR & $\begin{array}{l}\text { Slow loris seen in a forested area administered by the Housing Development Board } \\
\text { (HDB). }\end{array}$ \\
\hline 7 & 24 Jul 2003 & CCNR & No information available. \\
\hline 8 & 4 Sep 2003 & CCNR & Two individuals observed in a terentang tree Campnosperma auriculatum. \\
\hline 9 & 13 Sep 2003 & CCNR & One seen in the canopy of a terentang tree Campnosperma auriculatum. \\
\hline 10 & 15 Nov 2003 & CCNR & One seen feeding on sap on a tree trunk at around 21:00 h. A photograph was taken. \\
\hline 11 & 6 Dec 2003 & CCNR & One photographed at midnight by the observer. \\
\hline 12 & 21 Dec 2004 & CCNR & $\begin{array}{l}\text { One seen at around } 22: 30 \mathrm{~h} \text { on the opposite bank of the first stream, about } 7 \text { to } 8 \mathrm{~m} \text { up } \\
\text { in a tree. It did not flee but continued its own activity for about } 10 \text { min before it } \\
\text { disappeared into the dense canopy. }\end{array}$ \\
\hline 13 & 6 Jul 2005 & Near CCNR & A road kill noted from the previous day. \\
\hline 14 & 11 Sep 2005 & CCNR & $\begin{array}{l}\text { Two separate individuals were seen - one observed past midnight in an albizia tree Para- } \\
\text { serianthes falcataria, and another about } 50 \mathrm{~m} \text { away in another tree at around 01:15 h. }\end{array}$ \\
\hline 15 & 8 Nov 2005 & CCNR & One photographed by the observer. \\
\hline 16 & 27 May 2007 & $\begin{array}{l}\text { East Coast } \\
\text { Park }^{\mathrm{a}}\end{array}$ & $\begin{array}{l}\text { An unidentified species of slow loris seen resting on a stairway leading out to } \\
\text { park/bench near the sailing centre at } 16: 30 \mathrm{~h} \text {. The animal was about } 20 \mathrm{~cm} \text { and had } \\
\text { brown fur. No photographs available. }\end{array}$ \\
\hline 17 & 29 Dec 2007 & CCNR & $\begin{array}{l}\text { One observed at tree canopy climbing with quick jerky movements in the evening. } \\
\text { The loris was identified as a pygmy slow loris } N \text {. pygmaeus. }\end{array}$ \\
\hline 18 & 18 Jan 2008 & CCNR & $\begin{array}{l}\text { One observed clambering over a giant rattan Plectocomia elongata to cross the canopy } \\
\text { over the pipeline trail. }\end{array}$ \\
\hline 19 & 3 Mar 2008 & Not available & $\begin{array}{l}\text { One seen in a garden, 'ran along the verandah, then went up a tree'. This observation } \\
\text { was posted on a citizen journalism portal, the Straits Times STOMP. }\end{array}$ \\
\hline 20 & 31 May 2008 & CCNR & One seen in a tree at about $22: 00 \mathrm{~h}$. \\
\hline
\end{tabular}


Table 1 (continued)

\begin{tabular}{|c|c|c|c|}
\hline No. & Date & Location & Notes \\
\hline 21 & 17 Jan 2009 & BTNR & One individual seen at night. \\
\hline 22 & 24 Jan 2009 & CCNR & One individual seen at night. \\
\hline 23 & 11 Feb 2009 & Near CCNR & One road kill individual found in the morning. \\
\hline 24 & 24 May 2009 & CCNR & One individual observed at night. \\
\hline 25 & 25 Jul 2009 & CCNR & One individual observed just after midnight. \\
\hline 26 & 10 Oct 2009 & BTNR & One individual seen at night. \\
\hline 27 & 12 Dec 2009 & BTNR & One individual seen at night. \\
\hline 28 & 17 Oct 2010 & BTNR & One individual seen at night. \\
\hline 29 & 12 Dec 2010 & BTNR & One individual seen at night. \\
\hline 30 & 1 May 2011 & CCNR & One individual seen at night. \\
\hline 31 & 25 May 2011 & CCNR & One individual seen at night. \\
\hline 32 & 8 Sep 2011 & CCNR & One individual seen at night. \\
\hline 33 & 13 Mar 2012 & CCNR & One individual seen at night. \\
\hline 34 & 19 Apr 2012 & Near BTNR & One individual seen at night. \\
\hline 35 & 4 Aug 2012 & CCNR & One individual seen at night. \\
\hline 36 & 10 May 2013 & BTNR & $\begin{array}{l}\text { Starting from the visitor centre and going up the main road, it was seen in the forest on } \\
\text { the left, between the junctions of Rock Path and Catchment Path. It was about } 10 \text { to } \\
15 \mathrm{~m} \text { up in a tree. Photographs of the individual were taken. }\end{array}$ \\
\hline 37 & 12 Feb 2014 & $\begin{array}{l}\text { Bedok } \\
\text { Reservoir } \\
\text { Park }\end{array}$ & $\begin{array}{l}\text { An abandoned } N \text {. bengalensis was found lying on the ground by a member of the } \\
\text { public at around 18:00 h. The individual was rescued in a dehydrated state but died at } \\
\text { 23:00 h on the same day. }\end{array}$ \\
\hline
\end{tabular}

slow lorises for Singapore dropped dramatically after this, apart from occasional imports declared for zoological purposes.

Most of the records of $N$. coucang in Singapore came from both the BTNR and CCNR, and these records are shown in Table 1. Most of the observers are familiar with the wildlife of Singapore and have spent considerable time in the field observing wildlife. The slow loris is also known to exist on Pulau Tekong (see account by Lim et al. 2008), an offshore military-training island that is arguably Singapore's best-protected forested area. There have been recent records and sightings on the island, and the encounter rate of the greater or Sunda slow loris on Pulau Tekong is estimated to be 0.5 to $0.7 \mathrm{~km}^{-1}$ in the mature secondary forest habitats on the island ( $\mathrm{M}$. Chua pers. comm.). It is also clear from the records that sightings of the slow loris in Singapore have sharply increased in recent decades.

To our knowledge, news outlets only began to cover slow loris confiscations in 1999, our survey found 8 articles (Table 2). At least 8 individuals were covered in these articles, but further unreported cases are known in which animals were donated to or left outside the grounds of Singapore Zoo.

\section{DISCUSSION}

The only field sightings of Nycticebus spp. in the surveys led by the first author were made in NSSF. Remarkably, out of 3 surveys into the forest, slow lorises were encountered in 2, although one of these was N. pygmaeus. Prior to that, more than $80 \mathrm{~h}$ of surveys were conducted in 7 other sites without encountering any slow lorises. The amount of human traffic and other anthropogenic disturbances can affect the distribution of slow lorises. Forests in Singapore are bordered or fragmented by major roads and expressways, private housing estates, military-training grounds and recreational facilities like golf courses (Fig. 1). The combination of air, noise and light pollution, and insecticide and pesticide use result in very unfavourable living conditions for slow lorises. The average encounter rate for all the sites of $0.017 \mathrm{~km}^{-1}$ is much lower than the average of 0.66 to $0.74 \mathrm{~km}^{-1}$ for Peninsula Malaysia (Nekaris \& Nijman 2007). Slow lorises are cryptic animals, with the most reliable method of detection being eyeshine. However, this depends on slow lorises looking directly into the beam of the light source that the researcher is using, and hence field data are probably an underestimate of actual density. 
Table 2. Articles from local newspapers that mentioned trade and confiscation of slow lorises Nycticebus spp. in Singapore

\begin{tabular}{|c|c|c|}
\hline Date & Relevant notes & Reference \\
\hline 15 Jan 1999 & $\begin{array}{l}\text { Exotic animal trader fined SGD } \$ 7200 \text { for the possession of exotic animals, which } \\
\text { included } 2 \text { slow lorises. The } 2 \text { slow lorises were confiscated and handed to the zoo for care. }\end{array}$ & Chong (1999) \\
\hline 23 Sep 2001 & $\begin{array}{l}\text { Two years earlier, the zoo took in a slow loris that had had all its teeth pulled out to } \\
\text { prevent the animal from biting its owners. }\end{array}$ & Chong (2001) \\
\hline 6 May 2002 & $\begin{array}{l}\text { 'Just last month (April 2002), a slow loris confiscated from a pet shop had to have two } \\
\text { root canals and four fillings done to its teeth at the zoo. } \\
\text { Its sharp teeth had been cut to prevent it from inflicting a painful bite. The teeth and } \\
\text { sinus passages were infected, causing intense pain. It could have died from the infection.' }\end{array}$ & Arshad (2002) \\
\hline 7 Nov 2004 & $\begin{array}{l}\text { One slow loris was offered for sale over the Internet for SGD } \$ 480 \text {. Government officials } \\
\text { caught the seller eventually. This was with the help of a reader who posed as an } \\
\text { interested buyer. }\end{array}$ & $\begin{array}{l}\text { Kua \& Teh } \\
(2004)\end{array}$ \\
\hline 23 Dec 2004 & $\begin{array}{l}\text { On } 21 \text { Dec } 2004 \text {, acting on tip-offs, government and NGO staff raided a flat and } \\
\text { recovered } 26 \text { animals, which included a slow loris. }\end{array}$ & Yin J (2004) \\
\hline $\begin{array}{l}2 \text { August } \\
2005\end{array}$ & $\begin{array}{l}\text { 'Around the world, countless animals are removed from the wild every day and } \\
\text { sold as exotic pets. When Zai (above) came to the Singapore Zoo seven years ago, } \\
\text { it was in a pitiful state weak and too thin for an adult slow loris. The zoo vet confirmed } \\
\text { that its condition was the result of malnutrition. The family that kept Zai illegally hadn't } \\
\text { fed it well.' }\end{array}$ & $\begin{array}{l}\text { Wildlife } \\
\text { Reserves } \\
\text { Singapore } \\
(2005)\end{array}$ \\
\hline 24 Apr 2007 & $\begin{array}{l}\text { From time to time, the Singapore Zoo receives confiscated exotic animals, which } \\
\text { include slow lorises, etc. }\end{array}$ & $\begin{array}{l}\text { Nai \& Lim } \\
(2007)\end{array}$ \\
\hline 18 Jun 2013 & $\begin{array}{l}\text { 'Three rare ball pythons, two Indian star tortoises and a slow loris were among more } \\
\text { than } 30 \text { wild or endangered animals rescued from a flat here in the biggest seizure of } \\
\text { illegal wildlife from a home in } 11 \text { years.' The flat was raided on } 3 \text { June by government } \\
\text { agents acting on a tip-off, and the live animals were handed over to Wildlife Reserves } \\
\text { Singapore. }\end{array}$ & Tan (2013) \\
\hline
\end{tabular}

Slow lorises feed on insects and small vertebrates usually other, smaller insectivores such as geckosand such a diet requirement may draw them to the edge of the forest where these are more abundant (Johns 1986). This is not to say that they are strictly forest-edge species. On the contrary, new research also suggests that the greater incidence of encounters at forest edges could simply be due to the fact that they are more easily spotted there (Nekaris \& Streicher 2008). They could also be lunar phobic (Trent et al. 1977, Erkert 1989), which could indicate an aversion to bright lights. Starr et al. (2012) found that pygmy lorises in Cambodia are highly active during dark nights, while activity during bright moonlit nights is correlated with temperature. If this result can be extrapolated to the slow lorises in Singapore, where night temperatures are virtually constant throughout the whole year, then light becomes the main factor affecting activity levels. The level of development, density of human population and amount of traffic throughout Singapore ensures that bright lights are shining nearly everywhere on the island. While this enables humans to function in nocturnal hours, it becomes a highly stressful environment for light-shunning species. Regular mosquito fogging of private estates and military and recreational facilities adjacent to natural habitats will also have impacted the insect populations in these areas, reducing the availability of food resources and therefore resulting in lower or no slow loris sightings in the area. NSSF (Transect 1, Fig. 1) is a rather unique site in this study, as it is comparatively undisturbed. The forests there are largely contiguous, and the 2 roads immediate to the area are not major roads, and one of them is closed by 19:30 h. Within the forest, the 'trails' are actually pipelines that form part of Singapore's water supply network and some areas are swampy mud pools. The lack of proper, dry paths and the forest's relative inaccessibility (it is nearly $4 \mathrm{~km}$ from the nearest public car park) have made human traffic to the area at night extremely low. There is also no development next to it, unlike Bukit Timah, for example. All these factors might explain the higher densities of slow lorises surviving there.

One of the slow lorises encountered was N. pygmaeus, instead of the expected $N$. coucang. The slow loris was spotted high up in a $30 \mathrm{~m}$ tall terentang tree Campnosperma auriculatum. This would certainly be a released or escaped animal. A check with the CITES Authority in Singapore showed that a confis- 
cation of $N$. pygmaeus was made in 2001. There are occasional confiscations of slow lorises, with the most recent occurring on 3 June 2013 (Tan 2013). While it is uncertain how long Indochinese slow lorises can survive in Singapore's forests, we now know that the pygmy loris trafficking network includes Singapore. Also, enforcement officials are not trained or kept up to date with slow loris taxonomy, with documents likely to list only $N$. coucang despite evidence showing that other species are equally likely to pass through Singapore's ports.

Repatriation of confiscated exotics would require the accurate identification of these animals by geographic region (Schulze \& Groves 2004). Slow lorises have been mistakenly labelled in zoo exhibits and released in the wrong regions in the past. A lot of confusion can occur, especially when it comes to differentiating $N$. coucang of different origins, mainly Peninsula Malaysia, Sumatra and the Riau islands.

From the data in the CITES trade database, we found evidence of discrepancies in the numbers of reported slow lorises passing through Singapore. Where their numbers decreased, from Singapore to a shipping destination, it is possible that traders might have imported slow lorises and sold some off to local collectors, before pushing the remainder back onto the international markets. Where their numbers increased, the only likely explanation is that extra slow lorises from various sources were smuggled into the shipment. It is unlikely that the slow lorises were caught in the wild in Singapore by the hundreds, because, as mentioned earlier, their existence has always been doubted and hence, they are not common. Even if they were present in densities similar to those of Peninsula Malaysia as reported by Barrett (1981) or on Pulau Tekong, the $8.55 \mathrm{~km}^{2}$ of forest suitable for slow lorises in the Nee Soon Sector of the Central Catchment would harbour around 170 slow lorises, a number which could quickly be extirpated by local captures to pad the reexport numbers. Also, the numbers in the quasi-legal trade alone seem to be great enough to swamp any native slow loris population.

Legal action has been taken against exotic animal traders for dealing in slow lorises and other illegal wildlife species (see Chong 1999), and heavier penalties are meted out against illegal wildlife traders under the Endangered Species (Import and Export) Act (ESA). This piece of legislation supports CITES by controlling the importation, exportation and introduction from overseas of certain animals and plants, and parts of such animals and plants, and matters connected therewith. Under the Act, it is an offence to import and export any endangered species without a permit from the Agri-Food and Veterinary Authority of Singapore (AVA). It is also an offence to possess, sell, offer or expose for sale, or display to the public any of these species, if the individual has been illegally imported. Any person or company caught violating the ESA is liable to be prosecuted in court and fined up to a maximum of SGD\$50 000 for each animal or plant (but not to exceed an aggregate of SGD $\$ 500000$ ) and/or to imprisonment for a term of up to 2 yr. The decrease in seizures of illegal wildlife species in Singapore in recent times has been attributed to improved legislation such as the ESA and to greater enforcement efforts (Basu 2006). The number of slow lorises confiscated from each illegal wildlife raid is usually low (1 to 2 animals) and some confiscated or surrendered animals have missing teeth (Chong 2001) and/or are in a poor state of health (Arshad 2002, Anon 2005). The sale price of a slow loris has been reported to be SGD $\$ 480$ (Kua \& Teh 2004). Successful raids of the premises of wildlife traders depend on reliable tip-offs, co-operation between the AVA and the Animal Concerns Research and Education Society (ACRES), and the use of rewards for informants (Yin 2004). The rampant internet trade means that it will become increasingly challenging to police the trade in slow lorises and other endangered wildlife species, and a concerted effort between many parties (Kua \& Teh 2004) is certainly required to stem the sale of illegal wildlife species (Feng 2012).

Our study, as well as recent confiscation events show that trade in slow lorises in Singapore is probably still going on and at higher rates. Traders might have become more organised, and might have been able to collect slow lorises from the wild in larger numbers and devised strategies to export them. This could be because of the use of Singapore as a transit point between range states and client states. In such a case, the supply of slow lorises to Singapore would be more or less consistent, and traders could readily bring in a small fraction of the shipment for local clients before the others leave for the client states. If there really is a continual supply of slow lorises into Singapore, and they are periodically released after the owners tire of them, then the probability of sighting them is increased, which complicates the work of biologists. This also points to Singapore's role in global slow loris conservation. Even though Singapore has only native species, the illegal trade means that other species also pass through the ports of this trade-dependent state. If this, and other, routes of transit are shut off from the global supply chain, it would make it much harder for traffickers and poachers to maintain an economically viable trading net- 
work. This would greatly help conservation efforts for slow lorises in Singapore as well as in other range states. Singaporeans should also be educated about the illegality of slow lorises in the market and popular websites such as YouTube (Nekaris et al. 2013).

\section{CONCLUSION}

The present population of Nycticebus coucang in Singapore is clearly under threat as it is restricted to the forests of the rainforest nature reserves and the large offshore island of Pulau Tekong. The compilation of slow loris sightings shows that they still exist in forest remnants and with sustained, focused and regular surveys, a more reliable estimate of their population number could be established. Due to the lack of specimens collected by the British colonial naturalists, it is impossible to know, from historical records, what the exact status of $N$. coucang was in Singapore and if slow lorises were actually found here. We can, however, make inferences from their presence in surrounding habitats, and we do find a natural existence of $N$. coucang in Johore, southern Peninsular Malaysia and Sumatra. There is therefore a strong case for the existence of N. coucang in Singapore. The absence of proof should not be taken as proof of absence, as the early collectors missed a number of other arboreal and nocturnal species. For example, the red-cheeked flying squirrel Hylopetes spadiceus and short-nosed fruit bat Cynopterus sphinx were only discovered or recorded in Singapore after independence in 1965 (Davison et al. 2008). As it is, this is the first and only survey of the slow loris in the wild, in Singapore, to date. Habitat connectivity is vital to the survival of this species, as shown by road kills and the use of rattans and lianas in crossing canopy gaps. As such, the identification of forest gaps to be bridged with the planting of trees, or the use of rope bridges, may increase connectivity between forest patches for slow lorises. The illegal trade in lorises and the keeping of them as pets still occur in Singapore, and more collaborative conservation efforts between animal welfare organizations, government authorities and the public at large are needed to stem this phenomenon.

Acknowledgements. We thank Kelvin Lim, Norman Lim, Robert Teo, Chan Kwok Wai, Lim Swee Cheng, Marcus Chua and the rest of our colleagues for their records of slow lorises in Singapore. The Vertebrate Study Group of Nature Society Singapore and the Raffles Museum of Biodiversity Research at the National University of Singapore provided a valuable collection of sightings by past researchers.

\section{LITERATURE CITED}

Arshad A (2002) Reptile lovers to form society. The Straits Times Interactive, 6 May 2002, p 2. www.ecologyasia.com/ news-archives/2002/may-02/straitstimes.asia1.com.sg_ singapore_story_0,1870,118086,00.html

Barrett E (1981) The present distribution and status of the slow loris in Peninsular Malaysia. Malays Appl Biol 10: 205-211

Basu R (2006) Seizures of illegal wildlife at new low. The Straits Times 2 February 2006, p 6. www.wildsingapore.com/ news/20060102/060202-6.htm

Brook BW, Sodhi NS, Ng PKL (2003) Catastrophic extinctions follow deforestation in Singapore. Nature 424:420-423

Charles-Dominique P, Bearder SK (1979) Field studies of lorisid behaviour: methodological aspects. In: Doyle GA, Martin RD (eds) The study of prosimian behaviour. Academic Press, New York, NY p 567-629

Chong CK (1999) Animals crimes: other offenders. The Straits Times, 15 January 1999, p 50

Chong CK (2001) Wild target. The Straits Times, 23 September 2001, p 21

Davison GWH (2008) The red list categories. In: Davison GWH, Ng PKL, Ho HC (eds) The Singapore red data book: threatened plants and animals of Singapore, 2nd edn. The Nature Society, Singapore, p 1-4

Davison GWH, Ng PKL, Ho HC (2008) Fauna: mammals. In: GWH, Ng PKL, Ho HC (eds) The Singapore red data book: threatened plants and animals of Singapore, 2nd edn. The Nature Society, Singapore, p 248-267

Duckworth JW (1998) The difficulty of estimating population densities of nocturnal forest mammals from transect counts of animals. J Zool 246:466-468

Erkert HG (1989) Lighting requirements of nocturnal primates in captivity: a chronobiological approach. Zoo Biol 8(2):179-191

Feng Z (2012) Illegal animal trade active on local sites. The Straits Times, 24 December 2012, p A9. http://newshub. nus.edu.sg/news/1212/PDF/ANIMAL-st-24dec-pA9.pdf

Harrison JL (1966) Introduction to mammals of Singapore and Malaya. Singapore Branch, Malayan Nature Society, Singapore

Johns A (1986) Effects of selective logging on the behavioral ecology of West Malaysian primates. Ecology 67:684-694

Kua CS, Teh JL (2004) Slow loris quick bust. The New Paper, 6 November 2004. http://habitatnews.nus.edu.sg/index. php? entry=/trade/slowlorisbust.txt

Lim KPK, Subaraj R, Yeo SH, Lim N, Lane D, Lee BYH (2008) Mammals. In: Davison GWH, Ng PKL, Ho HC (eds) The Singapore red data book: threatened plants and animals of Singapore, 2nd en. The Nature Society, Singapore, p 190-207

Malone N, Purnama AR, Wedana M, Fuentes A (2002) Assessment of the sale of primates at Indonesian bird markets. Asian Primates 8:7-11

Nai W, Lim AK (2007) Loving them to death. The Straits Times, 24 April 2007, p 117

National Parks Board (2007) Facts and figures. In: National Parks Board Annual Report 2006/2007. National Parks Board, Singapore. www.nparks.gov.sg/cms/index.php? option=com_content $\&$ view=category $\&$ id=9\&Itemid=126 \#2006

Nekaris KAI, Bearder SK (2007) The strepsirrhine primates of Asia and mainland Africa: diversity shrouded in darkness. In: Campbell C, Fuentes A, MacKinnon K, Panger 
M, Bearder SK (eds) Primates in perspective. Oxford University Press, Oxford, p 24-45

Nekaris KAI, Jaffe S (2007) Unexpected diversity of slow lorises (Nycticebus spp.) within the Javan pet trade: implications for slow loris taxonomy. Contrib Zool 76(3): 187-196

Nekaris KAI, Nijman V (2007) CITES proposal highlights rarity of Asian nocturnal primates (Lorisidae: Nycticebus). Folia Primatol (Basel) 78:211-214

Nekaris A, Streicher U (2008) Nycticebus coucang. In: IUCN (2013) IUCN Red List of Threatened Species. Version 2013.2. www.iucnredlist.org

Nekaris KAI, Campbell N, Coggins TG, Rode EJ, Nijman V (2013) Tickled to death: analysing public perceptions of 'cute' videos of threatened species (slow lorises - Nycticebus spp.) on Web 2.0 sites. PLoS ONE 8:e69215

Ratajszczak R (1998) Taxonomy, distribution and status of the lesser slow loris Nycticebus pygmaeus and their implications for captive management. Folia Primatol 69: 171-174

Schulze H, Groves C (2004) Asian lorises: taxonomic problems caused by illegal trade. In: Nadler T, Streicher U, Ha TL (eds) Conservation of primates in Vietnam. Proc Int Symp Cuc Phuong National Park, 18-20 November 2003. Haki Publishing, Hanoi, p 33-36

Editorial responsibility: Anna Nekaris,

Oxford, UK
Shepherd C, Sukumaran J, Wich SA (2004): Open season: an analysis of the pet trade in Medan, Sumatra 1997-2001. TRAFFIC Southeast Asia, Selangor

Starr C, Nekaris KAI, Leung LKP (2012) A comparison of three survey methods for detecting the elusive pygmy slow loris Nycticebus pygmaeus in eastern Cambodia. Cambodian J Nat Hist 2012:123-130

Tan A (2013) Over 30 wild animals seized by AVA in a flat biggest inland seizure of wildlife since 2002. The Straits Times, 17 June 2013. www.straitstimes.com/breakingnews/singapore/story/over-30-wild-animals-seized-avaflat-biggest-inland-seizure-wildlife-2

Trent B, Tucker M, Lockard J (1977) Activity changes with illumination in slow loris Nycticebus coucang. Appl Anim Ethol 3:281-286

Wiens F, Zitzmann A (2003a) Social dependence of infant slow lorises to learn diet. Int J Primatol 24:1007-1021

- Wiens F, Zitzmann A (2003b) Social structure of the solitary slow loris Nycticebus coucang (Lorisidae). J Zool 261: $35-46$

Wildlife Reserves Singapore (2005) Slow but sure death. The Straits Times, 2 August 2005, p 16

Yin $J$ (2004) 37 illegal animals recovered in raids. Today, 23 December 2004, p 6. www.ecologyasia.com/newsarchives/2004/dec-04/to_041223_1.htm

Submitted: July 29, 2013; Accepted: February 28, 2014 Proofs received from author(s): July 7, 2014 